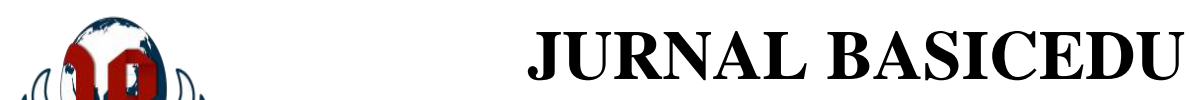

Volume 5 Nomor 4 Tahun 2021 Halaman 1834 - 1839

Research \& Learning in Elementary Education

https://jbasic.org/index.php/basicedu

\title{
Penggunaan Metode Snowball Throwing untuk Meningkatkan Hasil Belajar IPS di Sekolah Dasar
}

\author{
Faslia \\ Pendidikan Guru Sekolah Dasar, Universitas Muhammadiyah Buton, Indonesia \\ E-mail: dra.faslia13@gmail.com
}

\begin{abstract}
Abstrak
Penelitian ini bertujuan untuk mendeskripsikan pengunaan metode snowball throwing dalam meningkatkan hasil belajar IPS materi tokoh sejarah pada masa kerajaan islam siswa kelas V SD Negeri 1 Bungi. Penelitian ini adalah Penelitian Tindakan Kelas (PTK), penelitian dilakukan dalam dua siklus dengan dua kali pertemuan. Pertemuan dari setiap siklus terdiri dari tahap perencanaan, tindakan, pengamatan dan refleksi. Hasil penelitian menunjukkan bahwa pada siklus I belum memenuhi kriteria ketuntasan minimal (KKM) 70 pada pembelajaran IPS di mana dari jumlah 26 siswa terdapat 17 siswa atau 63,38\% yang hasil belajar sudah baik, sedangkan 9 siswa atau 34,62\% hasil belajar belum baik sehingga masih memerlukan tindakan pada siklus II. Pada siklus II hasil belajar siswa telah menunjukkan peningkatan dimana dari jumlah 26 siswa terdapat 23 siswa atau 88,46\% yang sudah tuntas, sedangkan 3 siswa yang belum tuntas atau 11,54\% sehingga target tindakan pada siklus II sudah baik. Dapat disimpulkan bahwa metode snowball throwing dapat meningkatkan hasil belajar siswa pada pelajaran IPS di Kelas V SD Negeri 1 Bungi.
\end{abstract}

Kata Kunci: Hasil Belajar, Metode Pembelajaran, Snowball Throwing.

\begin{abstract}
This study aims to describe the use of the snowball throwing method in improving social studies learning outcomes for historical figures during the Islamic kingdom period for fifth grade students of SD Negeri 1 Bungi. This research is Classroom Action Research (CAR), the research was conducted in two cycles with two meetings. The meeting of each cycle consists of planning, action, observation and reflection stages. The results showed that in the first cycle did not meet the minimum completeness criteria (KKM) 70 in social studies learning where from a total of 26 students there were 17 students or $63.38 \%$ whose learning outcomes were good, while 9 students or $34.62 \%$ of learning outcomes had not. good so it still requires action in cycle II. In cycle II, student learning outcomes have shown an increase where from the total 26 students there are 23 students or $88.46 \%$ who have completed, while 3 students have not completed or $11.54 \%$ so that the target of action in cycle II is good. It can be concluded that the snowball throwing method can improve student learning outcomes in social studies lessons in Class V SD Negeri 1 Bungi.
\end{abstract}

Keywords: Learning Outcomes, Learning Methods, Snowball Throwing.

Copyright (c) 2021 Faslia

Corresponding author :

Email : dra.faslia13@gmail.com

DOI $\quad$ : https://doi.org/10.31004/basicedu.v5i4.1046

ISSN 2580-3735 (Media Cetak)

ISSN 2580-1147 (Media Online) 
1835 Penggunaan Metode Snowball Throwing untuk Meningkatkan Hasil Belajar IPS di Sekolah Dasar Faslia

DOI: https://doi.org/10.31004/basicedu.v5i4.1046

\section{PENDAHULUAN}

Kualitas kehidupan bangsa sangat ditentukan oleh faktor pendidikan. Fungsi pendidikan cukup penting untuk menghasilkan kehidupan yang cerdas, damai, terbuka, dan demokratis. Kemajuan suatu bangsa hanya dapat dicapai melalui penataan pendidikan yang baik. Indonesia memposisikan pendidikan sebagai salah satu isu penting dan strategis. Hal ini dapat dilihat dari isi pembukaan UUD 1945 alinea IV yang menegaskan bahwa salah satu tujuan nasional bangsa Indonesia adalah mencerdaskan kehidupan bangsa.

Kualitas pendidikan kunci utamanya terletak pada mutu gurunya sehingga para pelaku pendidikan terutama guru diharuskan untuk menguasai dan mampu berinovasi baik dalam penggunaan sarana dan prasarana, metode pembelajaran demi tercapainya peningkatan kualitas pendidikan (Agustina, 2017). Keberhasilan peserta didik, terutama yang berhubungan dengan proses pembelajaran sangat dibutuhkan peran guru (Nurmaya.G, 2019).

Guru merupakan profesi yang memiliki peran yang amat penting dalam peningkatan kualitas pendidikan dan guru sebagai satu-satunya sumber informasi bagi peserta didik dalam Kurikulum Tingkat Satu Pendidikan Dasar SD/MI. Hasil belajar yang dicapai siswa dipengaruhi oleh dua faktor utama yakni faktor dari diri siswa dan faktor yang datang dari luar diri siswa atau faktor lingkungan. Faktor kemampuan siswa besar sekali pengaruhnya terhadap hasil belajar yang dicapai (Sudjana, 2019). Hasil belajar yang diperoleh siswa sangat berbanding lurus dengan kualitas pembelajaran, artinya bahwa semakin baik kualitas pembelajaran maka semakin baik hasil belajar yang diperoleh (Kusuma, 2021).

Faktor yang mempengaruhi hasil belajar itu diantaranya adalah (1) Faktor-faktor yang berasal dari luar diri pelajar, yang digolongkan menjadi dua golongan yaitu: (a) Faktor-faktor non-sosial dalam belajar. Faktorfaktor ini boleh dikatakan juga tak terbilang jumlahnya, misalnya: keadaan udara, cuaca, waktu, tempat (letaknya, pergedungannya), alat-alat yang disukai untuk belajar dan sebagainya. (b) Faktor-faktor sosial dalam belajar. Faktor-faktor sosial disini adalah faktor manusia (sesama manusia), baik manusia itu ada (hadir) maupun tidak langsung hadir. Jadi dapat dikatakan kehadiran orang atau orang-orang lain pada waktu seseorang sedang belajar, sangat mengganggu belajar. (2) Faktor-faktor yang berasal dari dalam diri pelajar, yang di golongkan menjadi dua yaitu: (a) Faktor-faktor fisiologis yaitu faktor-faktor yang berhubungan dengan kondisi fisik individu. Kondisi fisik yang bugar dan sehat akan memberikan dampak positif pada kegiatan belajar seseorang. (b) Faktor-faktor psikologis adalah keadaan psikologi seseorang yang dapat mempengaruhi proses belajar (Kurniawan et al., 2018).

Metode pembelajaran yang konvensional (umumnya ceramah) bisa mengakibatkan kejenuhan pada siswa karena peserta didik menjadi pasif (Hujaemah et al., 2015). Beberapa faktor psikologis yang mempengaruhi proses belajar adalah: (1) Kecerdasan/inteligensi peserta didik. Secara umum, kecerdasan dapat diartikan suatu kemampuan psikofisik terhadap reaksi, rangsangan atau menyesuaikan diri dengan lingkungan dengan cara yang tepat. (2) Motivasi. Motivasi adalah salah satu faktor yang mempengaruhi keaktifan kegiatan belajar peserta didik. Motivasilah dapat mendorong peserta didik untuk melakukan proses belajar mengajar.(3) Minat merupakan kecenderungan dan gairah yang cukup tinggi atau hasrat yang besar terhadap sesuatu. (4) Sikap individu dapat memberikan dampak keberhasilan proses belajar. Sikap adalah gejala internal yang berdimensi afektif berupa kecenderungan untuk mereaksi atau merespon dengan cara yang relatif tetap terhadap objek, orang, peristiwa, dan sebagainya. (5) Bakat. Secara umum bakat didefinisikan sebagai kemampuan potensial yang dimiliki seseorang untuk mencapai keberhasilan pada masa yang akan dating (Pingge, 2016).

Model yang dapat digunakan dalam pembelajaran Ilmu Pengetahuan Sosial (IPS) adalah metode Snowball Throwing (Santika \& Aulia, 2019). Metode snowball throwing merupakan metode yang menitik beratkan pada suatu pertanyaan yang diajukan dalam sebuah permainan (Wijayanthi et al., 2014). Di mana masing-masing siswa saling melempar bola-bola yang terbuat dari kertas, namun berisi tentang pertanyaan. 
Setiap individu yang terlibat dalam metode ini harus mempersiapkan diri untuk menjawab setiap pertanyaan yang diajukan oleh temannya (Sunistini Luh et al., 2013). Metode adalah seperangkat cara, jalan, dan teknik yang digunakan oleh pendidik dalam proses pembelajaran agar siswa dapat mencapai tujuan pembelajaran yang maksimal. Metode yang baik merupakan cara yang bisa meningkatkan semangat atau gairah peserta didik dalam mengikuti pelajaran (Afandi et al., 2013).

Tujuan metode pembelajaran Snowball Throwing melatih siswa untuk lebih tanggap menerima pesan dari orang lain, dan menyampaikan pesan tersebut kepada temannya dalam satu kelompok. Lemparan pertanyaan tidak menggunakan tongkat seperti metode pembelajaran Talking Stik akan tetapi menggunakan kertas berisi pertanyaan yang diremas menjadi sebuah bola kertas lalu dilempar-lemparkan kepada siswa lain. Siswa yang mendapat bola kertas lalu membuka dan menjawab pertanyaannya (. et al., 2017).

Metode snowball throwing dapat dijadikan sebagai salah satu variasi metode yang dapat digunakan untuk mengajarkan siswa SD kelas V semester 1. Peneliti tertarik untuk melakukan penelitian dengan judul Pengunaan Metode Swoball Throwing Untuk Meningkatkan Hasil Belajar IPS Materi Tokoh Sejarah Pada Masa Kerajaan Islam Siswa Kelas V SD Negeri 1 Bungi. Diharapkan dengan mengunakan metode snowball throwing hasil belajar siswa dapat meningkat.

Guru masih mengalami hambatan dalam menerapkan metode pembelajaran yang akurat dalam proses pembelajaran tematik, sehingga dalam mengimplementasikan pembelajaran tematik dengan model atau metode ketika kegiatan pembelajaran berlangsung sulit diterapkan (Handayani et al., 2021). Kondisi yang terjadi pada lokasi penelitian menunjukkan masih rendahnya hasil belajar siswa yang salah satu penyebanya adalah kurang antusiasnya siswa dalam mengikuti proses pembelajaran yang berlangsung. Metode Snowball Throwing dianggap penting karena dalam penggunaan metode ini mengharuskan siswa untuk lebih tanggap dalam menganalisis pesan dari orang lain. Metode ini sudah dilakukan oleh beberapa peneliti, namun tidak spesifik pada mata pelajaran Ilmu Pengetahuan Sosial melainkan mata pelajaran lain, sehingga metode ini coba diterapkan pada mata pelajaran Ilmu Pengetahuan Sosial di Sekolah Dasar.

\section{METODE PENELITIAN}

Penelitian ini merupakan jenis penelitian tindakan kelas yang diharapkan bisa menemukan model yang sesuai dalam meningkatkan hasil pembelajaran di sekolah dasar. Data penelitian dikumpulkan dengan menggunakan teknik tes dan observasi (Sam's, 2010:92). Adapun data tersebut terdapat bermacam-macam jenis metode. Jenis metode yang digunakan dalam pengumpulan data disesuaikan dengan sifat penelitian yang dilakukan. Metode-metode yang digunakan peneliti dalam mengumpulkan data tersebut adalah sebagai beikut: Tes, Observasi, dan Instrumen (Arikunto, 2002).

Teknik analisis data merupakan tindak lanjut kegiatan peneliti sesudah data terkumpul untuk segera digarap oleh staf peneliti untuk mengolah data. Data dari hasil pengamatan diolah dengan analisis deskriptif untuk menggambarkan keadaan peningkatan pencapaian indikator keberhasilan tiap siklus dan untuk menggambarkan keberhasilan metode Role Playing yang dapat meningkatkan hasil belajar siswa (Arikunto, 2002). Peneliti menerapkan metode Role Playing di kelas V SD dengan menggunakan siklus yang setiap siklusnya terdiri dari perencanaan, tindakan, observasi dan refleksi.

Rumus menghitung nilai presentase siswa adalah sebagai berikut (Indarwati et al., 2014):

$$
\mathrm{P}=\frac{\text { Siswa yang tuntas belajarnya }}{\text { Seluruh siswa }} \times 100 \%
$$


1837 Penggunaan Metode Snowball Throwing untuk Meningkatkan Hasil Belajar IPS di Sekolah Dasar Faslia

DOI: https://doi.org/10.31004/basicedu.v5i4.1046

\section{HASIL DAN PEMBAHASAN}

Penelitian ini dilakukan sebagai upaya untuk meningkatkan hasil belajar siswa dalam pembelajaran IPS melalui metode snowball throwing. Dengan menerapkan metode tersebut dalam pelajaran IPS siswa akan lebih aktif dan dapat lebih memahami materi secara mendalam.

Pelaksanaan penelitian ini dilakukan di kelas V dengan jumlah siswa 26 dengan materi IPS tokoh sejarah pada masa kerajaan islam yang dilaksanakan sebanyak 2 siklus. Sebelum melakukan tindakan peneliti melakukan pre test untuk mengetahui seberapa jauh pemahaman mereka tentang materi yang akan disampaikan pada siklus I. Dari analisa hasil pre test memang diperlukan tindakan untuk meningkatkan hasil belajar IPS materi tokoh sejarah pada masa kerajaan islam. Pelaksanaan tindakan siklus I dilaksanakan dengan alokasi waktu masing-masing siklus ( 2 X 35 atau 70 menit) jam pelajaran. Pelaksanaan penelitian mengacu pada prosedur penelitian yang telah ditetapkan sebelumnya yang meliputi tahap perencanaan, tindakan, observasi dan evaluasi serta refleksi. Pada tahap observasi dan evaluasi ini dibantu oleh guru pengamat dengan mengamati pelaksanaan tindakan yang berlangsung setiap siklus yang hasilnya dibahas pada tahap analisis dan refleksi. Pada tahap ini dilaksanakan dengan menggunakan lembar pengamatan. Pada tes awal siswa yang mendapatkan nilai $\geq 70$ berjumlah 10 dari 26 siswa dengan presentasi 38,46\% 10 siswa (8 siswa perempuan dan 2 siswa laki-laki) atau dengan presentase sebesar 38,46\% yang mampu mencapai nilai kriteria ketuntasan minimal (KKM). Sedangkan siswa yang belum tuntas sebanyak 16 siswa ( 8 siswa perempuan dan 8 siswa laki-laki) dengan presentase $61,54 \%$. Nilai yang sering muncul (modus) adalah 75 , nilai tertinggi dari data awal hasil belajar adalah 80 diperoleh dengan jumlah siswa sebanyak 2 orang sedangkan nilai terendah adalah 30 diperoleh dengan jumlah siswa sebanyak 2 orang.

Dalam pengambilan data pada observasi awal ini, ada beberapa hal yang perluh diperhatikan dan menjadi pertimbangan oleh peneliti untuk melaksanakan tahap selanjutnya, yakni sebagai berikut:

Pada saat PBM suasana kelas dalam keadaan ribut, dan sebagian siswa kurang serius dalam mengikuti pelajaran, masih ada yang keluar masuk kelas serta menganggu temannya pada proses pembelajaran siswa terlihat masih kurang paham tentang materi yang diberikan.

Berdasarkan analisis data di atas yang diperoleh peneliti, maka ada beberapa hal yang perlu diperbaiki dalam kegiatan pra tindakan yakni hasil belajar siswa dalam materi yang diajarkan sangat minim dan belum optimal. jika dilihat dari keseluruhan yakni rata-rata daya serap siswa hanya 58,65\%.

Tabel 1. Hasil siklus 1

\begin{tabular}{llc}
\hline No & \multicolumn{1}{c}{ Uraian } & Hasil Siklus I \\
\hline 1. & Nilai rata-rata tes formatif & $61,15 \%$ \\
2. & Jumlah siswa yang tuntas belajar & 17 \\
3. & Persentase ketuntasan belajar & $65,38 \%$ \\
\hline
\end{tabular}

Dari hasil observasi peneliti, tampak terjadi pergeseran nilai hasil belajar dari tes awal ke siklus I sudah menunjukkan peningkatan nilai. Nilai siklus 1 yang memperoleh nilai $\geq 70$ adalah 17 orang atau $65,38 \%$ dan 9 siswa yang memiliki nilai $\leq 70$ atau 34,62 dengan nilai rata-rata $61,15 \%$.

Pada kegiatan guru dalam mengajar hasil observasi dan pengamatan akan terlihat bahwa pada siklus I. Pengamatan yang dilaksanakan oleh guru pengamat dengan memperhatikan data hasil kegiatan belajar mengajar siklus I pada tabel yang disediakan.karena hasil pada siklus I belum memuaskan/belum mencapai ketuntasan maka dilanjut pada siklus II.

Berdasarkan hasil observasi pada tindakkan siklus II, peeneliti dan siswa telah melakukan kegiatan pembelajaran sesuai dengan yang diharapkan. Kekurangan pada tindakan siklus I sudah dapat diperbaiki peneliti sudah mampu menguasai kelas dan siswa sudah bisa menyesuaikan dengan kelompok belajar yang 
telah ditetapkan oleh peneliti, selain itu siswa sebagian besar sudah terlihat aktif dalam mengikuti kegiatan pembelajaran.

Tabel 2. Hasil siklus 2

\begin{tabular}{llc}
\hline No & \multicolumn{1}{c}{ Uraian } & Hasil Siklus II \\
\hline 1. & Nilai rata-rata tes formatif & $88,46 \%$ \\
2. & Jumlah siswa yang tuntas belajar & 23 \\
3. & Persentase ketuntasan belajar & $86,15 \%$ \\
\hline
\end{tabular}

Terlihat dari hasil belajar yang dimiliki siswa yaitu siswa yang memliki hasil belajar $\geq 70$ adalah 23 siswa dengan presentase $88,46 \%$ sedangkan yang tidak memperoleh nilai $\leq 70$ berjumlah 3 siswa dengan presentase $11,54 \%$ jadi rata-rata $86,15 \%$, hasil ini telah menunjukan bahwa pada siklus II ini hasil belajar siswa meningkat dari siklus I dan telah mencapai nilai KKM.

Dari hasil evaluasi siswa yang diperoleh pada tindakan siklus II, dapat dikatakan bahwa pengunaan metode snowball throwing, telah memberikan dampak yang baik terhadap kemampuan siswa, kemampuan dalam menyelesaikan soal-soal IPS, serta memberikan memotivasi kepada siswa untuk belajar. Meskipun pada akhir siklus II masih ada 3 siswa yang belum tuntas belajar dan siswa masih ada yang kesulitan untuk membuat kesimpulan. Karena indikator keberhasilan dalam penelitian ini telah mencapai minimal $85 \%$ siswa telah mencapai nilai $\geq 70$, maka penelitian ini dihentikan pada siklus II. Ini berarti hasil belajar IPS dapat meningkat dengan menggunakan metode snowball throwing pada kelas V SD Negeri 1 Bungi.

Keberhasilan pembelajaran sangat ditentukan oleh peran guru dalam mendesain model pembelajaran yang sesuai dengan kebutuhan peserta didik dan keadaan sumber daya yang tersedia. Dari hasil dan pembahasan menunjukkan bahwa terjadi peningkatan hasil belajar siswa dari proses pelaksanaan pra tindakan, sampai pada siklus ke dua menunjukan penggunaan metode Snowball Throwing dapat meningkatkan hasil belajar siswa mata pelajaran Ilmu Pengetahuan Sosial (IPS) kelas V di SD Negeri 1 Bungi.

\section{KESIMPULAN}

Penelitian ini memberikan kesimpulan yang menunjukkan bahwa ada peningkatan yang terjadi setiap penggunaan metode snowball throwing, dibuktikan dengan perubahan angka persentasi ketuntasan hasil belajar siswa yang terjadi antara pra siklus dengan siklus pertama, setelah dilanjutkan pada siklus ke dua, juga terjadi peningkatan dari siklus kepertama. Sehingga dapat disimpulkan bahwa penggunaan metode snowball throwing dapat meningkatkan hasil belajar siswa kelas V SD pada mata pelajaran Ilmu Pengetahuan Sosial (IPS).

\section{UCAPAN TERIMA KASIH}

Ucapan terimakasih kepada Rektor Universitas Muhammadiyah Buton yang telah mendukung kelancaran penelitian hingga artikel ini dan dapat terbit. Kepada berbagai pihak yang sudah berkontribusi dalam penyelesaian artikel penelitian ini.

\section{DAFTAR PUSTAKA}

M. W. A., . D. K. A. S. S. M. S., \& . I. G. P. S. S. P. . M. P. (2017). Pengaruh Model Pembelajaran Kooperatif Tipe Snowball Throwing Terhadap Hasil Belajar Siswa Pada Mata Pelajaran TIK Kelas VIII SMP Negeri 5 Tejakula. Kumpulan Artikel Mahasiswa Pendidikan Teknik Informatika (KARMAPATI). https://doi.org/10.23887/karmapati.v6i1.9567 
1839 Penggunaan Metode Snowball Throwing untuk Meningkatkan Hasil Belajar IPS di Sekolah Dasar Faslia

DOI: https://doi.org/10.31004/basicedu.v5i4.1046

Afandi, M., Chamalah, E., \& Wardani, O. P. (2013). Model Dan Metode Pembelajaran Di Sekolah. In Perpustakaan Nasional Katalog Dalam Terbitan (KDT). https://doi.org/10.1007/s00423-006-0143-4

Agustina, E. T. (2017). IMPLEMENTASI MODEL PEMBELAJARAN SNOWBALL THROWING UNTUK MENINGKATKAN HASIL BELAJAR SISWA DALAM MEMBUAT PRODUK KRIA KAYU DENGAN PERALATAN MANUAL. Innovation of Vocational Technology Education. https://doi.org/10.17509/invotec.v9i1.4881

Arikunto, S. (2002). Metodologi Penelitian Suatu Pendekatan Proposal. 2017.

Handayani, S. L., Budiarti, I. G., Kusmajid, K., \& Khairil, K. (2021). Problem Based Instruction Berbantuan E-Learning: Pengaruhnya terhadap Kemampuan Berpikir Kritis Peserta Didik Sekolah Dasar. Jurnal Basicedu. https://doi.org/10.31004/basicedu.v5i2.795

Hujaemah, E., Saefurrohman, A., \& Sultan Maulana Hasanuddin Banten, U. (2015). Pengaruh Penerapan Model Snowball Throwing Terhadap Hasil Belajar Ipa Di Sekolah Dasar. Terbit Sejak.

Indarwati, D., Wahyudi, W., \& Ratu, N. (2014). PENINGKATAN KEMAMPUAN PEMECAHAN MASALAH MATEMATIKA MELALUI PENERAPAN PROBLEM BASED LEARNING UNTUK SISWA KELAS V SD. Satya Widya. https://doi.org/10.24246/j.sw.2014.v30.i1.p17-27

Kurniawan, B., Wiharna, O., \& Permana, T. (2018). Studi Analisis Faktor-Faktor yang Mempengaruhi Hasil Belajar pada Mata Pelajaran Teknik Listrik Dasar Otomotif. Journal of Mechanical Engineering Education. https://doi.org/10.17509/jmee.v4i2.9627

Kusuma, Y. Y. (2021). Peningkatan Hasil Belajar SIswa dengan Menggunakan Model Pembelajaran Problem Based Learning di Sekolah Dasar. Jurnal Basicedu. https://doi.org/10.31004/basicedu.v4i4.753

Nurmaya.G, A. L. (2019). PERANAN MANAJEMEN KELAS DALAM MENINGKATKAN EFEKTIVITAS PEMBELAJARAN DI SEKOLAH DASAR. Jurnal Basicedu. https://doi.org/10.31004/basicedu.v3i2.275

Pingge, H. D. (2016). FAKTOR YANG MEMPENGARUHI HASIL BELAJAR SISWA SEKOLAH DASAR DI KECAMATAN KOTA TAMBOLAKA. Jurnal Prima Edukasia. https://doi.org/10.21831/jpe.v4i2.6458

Santika, M., \& Aulia, W. (2019). PENINGKATAN AKTIVITAS BELAJAR SISWA MELALUI MODEL SNOWBALL THROWING DI SEKOLAH DASAR. Jurnal Basicedu.

Sudjana, N. (2019). Dasar-Dasar Proses Mengajar. In Bandung: Sinar Baru Algensindo.

Sunistini Luh, Arini, N. W., \& Margunayasa, I. G. (2013). Penerapan Model Snowball Throwing Berbantuan Media Sederhana Untuk Meningkatkanhasil Belajar Matematika Siswa Di Sd No 1 Petandakan. MIMBAR PGSD Undiksha.

Wijayanthi, M. R., Suarjana, M., Riastini, N., Guru, J. P., \& Dasar, S. (2014). PENERAPAN METODE PEMBELAJARAN SNOWBALL THROWING UNTUK MENINGKATKAN HASIL BELAJAR IPA SISWA KELAS V SD. Jurnal Mimbar PGSD Universitas Pendidikan Ganesha Jurusan PGSD. 